\title{
SEPARATION OF OWNERSHIP AND CONTROL IN SOUTH AFRICAN-LiSTEd COMPANIES
}

\author{
Blanché Steyn
}

School of Business and Economics, Monash South Africa

Lesley Stainbank

School of Accounting, Economics and Finance, University of KwaZulu-Natal

Accepted: March 2013

\begin{abstract}
This article tests the separation of ownership and control in South African-listed companies that leads to the divergence of interest between shareholders and directors. Where listed companies are owned by so many shareholders that their diffused shareholding results in negligible control over the directors who manage the assets of the company, it is likely that the directors will manage and direct the company to maximise their self-interest to the detriment of the interest of the shareholders. The separation of ownership and control and the maximisation of self-interest are central themes in the agency theory. Researching their validity in a South African context where the market is less liquid and the stock exchange is significantly smaller can add a valuable contribution to the continuing debate on corporate governance in the country.

The article analyses 186 listed South African companies using data extracted over four years to test whether there is separation of ownership and control and whether such separation leads to the maximisation of self-interest. Data were extracted for the years 2005 and 2006, using the shareholding in 2006 to determine control, and for the years 2009 and 2010, using the shareholding in 2010 to determine control. Directors' remuneration as a percentage of assets was used as a proxy for the maximisation of directors' interest, and profit attributable to shareholders as a percentage of assets was used as a proxy for the maximisation of shareholders' interest. These proxies were used to test the impact of control during the two controlling periods, namely 2006 and 2010.

The article finds that the majority of listed companies in South Africa are controlled by a dominant shareholder. However, there are still a significant number of companies where the directors have de facto control. Contrary to the expectation that companies controlled by directors will aim to maximise directors' remuneration, or companies controlled by shareholders will aim to maximise profit attributable to shareholders, this article finds the opposite to be true. This is possibly an indication that the controlling parties might consider factors other than their direct financial self-interest, or that there is an inherent cost associated with control.
\end{abstract}

Key words: separation of ownership and control; goal divergence; maximisation of self-interest

JEL: M20, 52

1

\section{Introduction}

This article aims to determine whether there is separation of ownership and control in South African-listed companies and, if there is, whether the controlling party acts to maximise his/her self-interest to the detriment of the other party. Thus this article questions whether separation of ownership and control over companies and the maximisation of selfinterest that develops from it, as theorised by
Berle and Means (1933), is a major factor for listed companies in the South African context.

The seminal work of Berle and Means (1933:95) was based on 200 large nonfinancial corporations listed in New York in the United States of America (USA), and successfully focused attention on the separation of ownership and control in modern corporations and the maximisation of selfinterest. According to Cheffins and Bank (2009:443) the contribution of the Berle and Means thesis is that 'separation of ownership 
and control was a hallmark of large U.S. corporations, and their characterization of matters ... had a profound and enduring influence on debates about corporate governance'. This was despite the fact that their 'data did not offer unequivocal proof of their separationof-ownership-and-control thesis' (Cheffins \& Bank, 2009:454). The current standing of the contribution of the work of Berle and Means is acknowledged by Bratton (2001:737-738) who stated that 'Berle and Means retain an enviable place at the forefront of policy discussion in a field where even a highly successful academic contribution rarely has a shelf life exceeding ten years.'

The separation of ownership and control plays a key role in the agency theory and the use of agency cost to manage the agency problem caused by divergence of interest (Jensen \& Meckling, 1976:308; Fama \& Jensen, 1983a:328-330; 1983b:312). With the development of agency cost as a mechanism to manage the divergent interest of shareholders and directors, Jensen and Meckling (1976) successfully linked the agency problems to the separation of ownership and control through the management of agency cost. Afshan, Chhetri and Pradhan (2011:82) note that corporate governance was developed to address the problems caused by the separation of ownership and control, while Cho and Kim (2007) state that '[e]ffective governance mechanisms have, since the study conducted by Berle and Means ... been identified as a requirement for solving the agency problems'. Guidance on corporate governance in South Africa is given via the different King codes of governance issued by the South African Institute of Directors (IoD) (IoD, 1994; 2002; 2009). King 1 acknowledges the existence of the separation of ownership and control in the statement that 'corporate governance is essentially only relevant where there is a division between the owners of equity and the directors of the business' (IoD, 1994:5). This statement was, however, not based on substantiating empirical evidence. The only prior South African research article that considered ownership and its impact on management and shareholders was by Cohen and Uliana (1990). Their article considered the impact of the basis of control for owner- controlled, foreign-controlled and conglomerate companies on employee, management and shareholder compensation and found that they are statistically indistinguishable, concluding that there is goal congruence (Cohen \& Uliana, 1990:12). The assumption of the agency theory that there is separation between ownership and control is not necessarily valid globally as not all countries have the diffusion of ownership that is an agency theory assumption (Dalton, Hitt, Certo \& Dalton, 2007:41). Care must be taken not to generalise the findings of ownership and other governance related studies performed in developed countries to developing countries (Afshan et al., 2011:89), highlighting the need for research in developing countries.

This article focuses on testing the assumption that firstly there is a split between the owners as shareholders and directors as managers (separation of ownership and control) of a company, and secondly the reliance on the neo-classical economic assumption that the parties will maximise their self-interest leading to goal divergence. Goal divergence problems stemming from the separation of ownership from control was assumed to exist as described by Rossouw, van der Watt and Malan (2002:289) who noted that the 'concept of corporate governance was born out of the agency problem that arose when the ownership of companies became separated from the control thereof'. As the separation of ownership and control and the maximisation of self-interest are central agency theory themes, researching their validity in a South African context, where the market is less liquid and the stock exchange is smaller, can add a valuable contribution to the continuing debate on corporate governance in the country.

This article uses two controlling periods to determine control for 186 companies listed on the Johannesburg Stock Exchange (JSE) and then identifies if control leads to the maximisation of self-interest. Self-interest maximisation occurs when the controlling parties maximise their direct self-interest to the detriment of the non-controlling parties. Directors' remuneration is used as a proxy for the interest of directors, and profit attributable to shareholders is used as a proxy for the interest of shareholders, as these are the most 
direct links to the possible controlling parties. Given the assumption of self-interest, it was expected that companies controlled by directors will have higher levels of directors' remuneration, and that companies controlled by shareholders would have higher levels of profit attributable to shareholders. The article found the opposite to be true.

The rest of the article is structured as follows. Section 2 describes the origin of separation of ownership from control, the roles of the shareholders and directors in the maximisation of self-interest that result from their goal divergence. The research questions are described in section 3 followed by a brief description of the methodology used in this study in section 4 . The results are described in section 5, followed by the conclusion, the limitations of the study and possible areas for future research discussed in section 6 .

\section{2}

\section{Separation of ownership and control}

Separation of ownership and control became more prominent with the development of limited liability companies. These deviated from the entrepreneurial model as the shareholders and providers of the funds and the residual claimants in the company are entitled to the rewards of ownership but were not directing the actions of the company that generated the rewards (Dalton et al., 2007:5). The new separate role of the shareholders as the provider of funds is described by Berle and Means as:

The property owner who invests in a modern corporation so far surrenders his wealth to those in control of the corporation that he has exchanged the position of independent owner for one in which he may become merely recipient of the wages of capital (Berle \& Means, 1933:3).

Separation of ownership and control distinguishes between the role and people involved in directing the company, the directors, and the shareholders or owners who provide funds. The shareholders need not have any other involvement in the company, in contrast to the entrepreneurial model where the owner provided the funds, directed the business and reaped the rewards. As this article focuses on the separation of ownership and control, the role of other providers of finance for the business, such as the use of loans, falls outside the scope of this article and is a limitation of this study.

The separation of ownership and control was tested in the USA by Stigler and Friedland (1983) as part of their assessment of the Berle and Means publication. Both studies found that 44 per cent of the corporations did not have effective shareholder control (Berle \& Means, 1933:94; Stigler \& Friedland, 1983:238), leading to de facto control by the directors for 44 per cent (less than half) of the corporations in the sample. Thus the separation of ownership and control is not necessarily widespread. Shareholders are powerful, with their powerbase grounded in their voting rights that are protected by the Companies Act issued by the Republic of South Africa (RSA) (RSA, 2008). This can result in control of a company by a large shareholder through voting rights. Tsipouri and Xanthakis (2004:18) emphasised the impact of self-maximisation of shareholders in 'the stronger voting control by large investors ... can pressure the management into profit maximization'. The separation of ownership and control need not be a disadvantage or constant struggle between directors and shareholders, as Fama and Jensen (1983a:330) found that 'the survival of complex organizations is enhanced by common stock residual claims that allow specialization of management'. This is also in line with the findings of Alchian and Demsetz (1972:777) who highlighted that the use of specialist managers can help to increase productivity. Therefore, there is an underlying economic benefit through increased profit based on increased productivity in separating the role of the shareholders from the role of the directors who manage the resources of the company. As this article focuses on the separation of ownership and control with the shareholders as residual claimants against the net assets of the company, other sources of funding through loans are not taken into consideration. Although companies also use loans to help fund the activities of a company, the returns on loans are fixed per the terms of the loan agreements. Other studies summarised 
by Cheffins and Bank (2009:467-474) that also focused on the separation of ownership and control in the USA are summarised in Table 1.

The prior research described in Table 1 focused on companies in the USA, a developed market, and showed an increase in separation of ownership from control. The replication of the Berle and Means study using companies from 1963 and 1974 showed a marked increase in separation of ownership from control with de facto control in the hands of the directors in
85 per cent and 83 per cent of the companies. The study of the Fortune 500 companies in 1967 found that directors had de facto control in 70 per cent of the companies. The diffusion of the shareholding is highlighted by the 1980 Fortune 500 companies' study that found that 78 per cent of the shareholders owned a 5 per cent plus shareholding with the average largest shareholder holding only 15.4 per cent of the shares (Cheffins \& Bank, 2009:467-474).

Table 1

Literature on ownership and control

\begin{tabular}{|l|l|l|}
\hline \multicolumn{1}{|c|}{ Authors } & \multicolumn{1}{|c|}{ Sample } & \multicolumn{1}{c|}{ Findings } \\
\hline Larner, 1966 & $\begin{array}{l}\text { Replicated Berle and Means as of } \\
1963\end{array}$ & $\begin{array}{l}\text { Privately owned 2\%, majority owned 3\%, minority control 9\%, } \\
\text { control by legal device 4\% and no base of control 85\%. }\end{array}$ \\
\hline Fortune, 1967 & 1967 Fortune 500 & $\begin{array}{l}30 \% \text { of the Fortune } 500 \text { companies were proprietary or } \\
\text { ownership controlled. }\end{array}$ \\
\hline Herman, 1981 & $\begin{array}{l}\text { 200 largest non-financial companies } \\
\text { ranked by assets and sales in 1974 }\end{array}$ & $\begin{array}{l}2 \% \text { were majority owned, 0.5\% government owned, 0.5\% } \\
\text { financial control, 0.5\% receivership, 15\% minority ownership } \\
\text { leaving 83\% controlled by management. }\end{array}$ \\
\hline Demsetz, 1983 & 50 companies & $\begin{array}{l}\text { Directors and officers collectively owned } 17.5 \% \text { of the shares } \\
1973-1982 .\end{array}$ \\
\hline $\begin{array}{l}\text { Shleifer and } \\
\text { Vishny, 1986 }\end{array}$ & $\begin{array}{l}\text { Fortune 500 as of 1980 excluding 44 } \\
\text { companies that were subsidiaries, } \\
\text { cooperative, privately held, or merged }\end{array}$ & $\begin{array}{l}78 \% \text { of the sample has shareholders owning a 5\%+ stake, } \\
\text { with the average largest shareholder at } 15.4 \% \text { of the shares. }\end{array}$ \\
\hline
\end{tabular}

Source: Cheffins and Bank, 2009:467-474

\subsection{The role of shareholders}

Shareholders are the residual claimants against the net assets of the company, as they bear the residual risk (RSA, 2008:section 37(3)(b)(ii)). Their shareholding is bonded in the company and is used by the directors to fund the activities of the enterprise (Fama \& Jensen, 1983a:330). Thus from a self-interest point of view, shareholders are motivated to maximise the profit attributable to them as they are the providers of funding and can be rewarded through dividends, gains in the value of their shares or distributions as residual claimants. An example of the maximisation of shareholders' interest was found by Jiang, Habib and Smallman (2009:124), who discovered that high ownership concentrations are negatively associated with CEO compensation in New Zealand.

\subsection{The role of directors}

In contrast, as directors receive directors' remuneration, their self-interest might cause them to direct the company in a manner that increases their directors' remuneration to the detriment of the profit attributable to the shareholders. As directors' remuneration is an expense, it directly influences the determination of profit attributable to shareholders. The directors are the specialist managers who coordinate the activities and manage the use of resources in the company to ensure the business of the company can flourish and generate profit. Goal divergence is especially likely in situations where the shareholdings of the directors are so small that they cannot be personally motivated using the same profit incentive that motivates the shareholders.

One of the recommended governance mechanisms is to use shares to encourage directors to act in the best interest of the shareholders. Singh and Davidson (2003:814) found that "higher inside ownership aligns managerial and shareholders' interests and lowers the agency costs in large corporations". This raises a concern that when the directors hold little equity and the shareholders are dispersed, the directors can use the assets of 
the company to benefit themselves rather than the shareholders (Morck, Shleifer \& Vishny, 1988:293). Such a concern is not unrealistic as there were massive misstatements in the financial statements of Enron leading up to its demise with managers who made enormous profits (Westbrook, 2003:64). This risk can be addressed through disclosure requirements requiring directors to disclose their remuneration. Such disclosures help to ensure shareholders and other stakeholders are aware of the benefits received by directors.

Examples of some of the disclosed benefits include a $£ 5.7$ million tax bill paid by Barclays for their CEO (Treanor, 2012), and the 2009 payment by Berkshire Hathaway for personal and home security to the value of $\$ 344490$ for Warren Buffet, its CEO (Stempel, 2010). The disclosure requirement of directors' remuneration does not necessarily hamper the ability of directors to maximise their own self-interest to the detriment of the shareholders, but it does reduce information asymmetry. Hill and Yablon (2002:298-299) found that the CEO of the National Australia Bank was the second highest paid executive despite a A\$4 billion write-down associated with the failed HomeSide venture, and that the board of Adelaide Bank increased its CEO's salary by 30 per cent while keeping dividends constant despite record profits. The latter clearly shows a bias by the board to favour a director, supporting the self-interest maximisation assumption.

\subsection{Goal divergence between shareholders and directors}

Assuming the maximisation of self-interest, shareholders have different goals from directors. This goal divergence is also referred to as the agency problem. Although there are many studies highlighting different governance mechanisms that can be used to achieve goal concurrence (Jensen \& Meckling, 1976; Fama \& Jensen, 1983a; 1983b; Jensen \& Murphy, 1990; O'Sullivan \& Diacon, 1999; Jensen, 2001; Cremers \& Nair, 2005; Shapiro, 2005; Babatunde \& Olaniran, 2009; Setia-Atmaja, 2009; Ward, Brown \& Rodriguez, 2009), this article focuses on investigating the separation of ownership and control and the maximisation of direct financial self-interest that can cause goal divergence. How any such goal divergence should be managed using corporate governance mechanisms falls outside the scope of this article, and is an area for future research.

\section{3}

\section{Research questions}

This article answers the following two research questions to achieve the aim of the study:

1) Is there separation of ownership and control in South African-listed companies?

2) Does the controlling party maximise his/her self-interest to the detriment of the other party?

To answer these two questions information was extracted for 186 listed companies on the JSE across all boards. The companies had to be active, not suspended from the JSE, not be part of major merger or takeover activities, be trading under the same name with total assets, directors' remuneration and profit or loss attributable to shareholders and with identifiable major shareholders for the 2006 and the 2010 control periods.

In this article, profit attributable to shareholders is used as the proxy for shareholders' interest, while directors' remuneration is used as a proxy for directors' interest, in line with the executive compensation and profitability measures used by Berle and Means (1933:94) and Stigler and Friedland (1983:249, 254). To facilitate comparability of the profit and directors' remuneration between the different companies, the profit attributable to ordinary shareholders and directors' remuneration, both are contextualised as a percentage of the total assets of their respective companies including intangible assets as shareholders are the residual risk takers in the company. Total assets were used to contextualise the rewards attributable to directors and shareholders as the total assets of the company were used to generate those rewards.

The use of profit attributable to shareholders is because shareholders maximise their direct interest when profit is maximised and could be prepared to accept more risk for the chance of higher profit. The maximisation of shareholder value is already integral to the ideology of capital markets (Lee, Michie \& Oughton, 
2003:92). A driving factor of shareholder value is the ability of a company to generate profits. In contrast, directors might be more conservative in their acceptance of risk, focusing on smaller more assured profit opportunities while maximising directors' interest through increased directors' remuneration, or alternatively direct the company towards safer, more constant but lower income-generating investments (Garen, 1994:1178). Brennan and Solomon (2008:585) note that the risk aversion of directors could motivate them to act in their own interest rather than contribute to shareholder value maximisation. In companies where there is no strong shareholder control, there is seemingly little direct oversight over the directors, and it could be possible for directors to positively influence their remuneration or reduce profitability by positioning the company towards safer investments that yield lower returns. This results in a risk of maximisation of directors' remuneration when the directors are in control and a director can 'guarantee his appointment with the firm at an attractive salary' (Morck et al., 1988:294).

Financial data for the 186 companies were extracted for the years 2005 and 2006, using the shareholding in 2006 to determine control, and for the years 2009 and 2010 using the shareholding in 2010 to determine control. In order to obtain useful and comparable data the information on the companies was extracted using Blink on the McGregor's BFA database, with the major shareholder and controlling interest in the companies identified using Profile's Stock Exchange Handbook for 2006 and 2010 (Profile, 2006; 2010). The article uses only the two controlling periods 2006 and 2010 to answer the research questions.

\subsection{Is there separation of ownership and control in South African-listed companies?}

In order to answer the first research question the companies were divided into two groups for each controlling period depending on their controlling influence. The first group consists of companies controlled by a dominant shareholder, referred to as shareholder controlled. In the absence of a controlling shareholder, the company was deemed to be controlled by the directors to form the second group, director controlled, unless directors' control was specifically indicated. Where directors in the company were also listed as major shareholders, the controlling interest is shown under shareholder controlled, because it is the voting right as a shareholder that renders the strongest level of control. The recorded shareholding of the largest major shareholder was used to answer the first research question.

Control rests with the power to exercise a controlling vote. The Companies Act, 71 of 2008 requires a 25 per cent shareholding and three people to form a quorum at a shareholders' meeting, making it possible for a major shareholder, with a shareholding as small as 25 per cent, to approve resolutions at a meeting in situations where the rest of the shareholding is more widely diffused (RSA, 2008:section 64). It is difficult to ascertain real control, because it is seldom possible to determine with certainty which shareholders or combination of shareholders have the power to appoint directors in situations where the controlling interest is not disclosed, or not evident from a shareholding of more than 50 per cent. Legally a shareholding greater than 50 per cent has the power to appoint the directors but, as described above, on a practical level, a lower dominant and uncontested shareholding could have enough voting rights to appoint the directors and control the company. For practical purposes the controlling cut-off used in this article is the lowest percentage of shareholding that was disclosed in Profile as a controlling interest (Profile, 2006; 2010). The choice of a specific cut-off point for practical purposes was because the identity of the controlling party was only disclosed in Profile for 28 companies (15.05 per cent) in 2006 and 16 companies (8.6 per cent) in 2010 (Profile, 2006; 2010). This resulted in 25 per cent being used as the cut-off point to indicate shareholder control, as 25.1 per cent was the lowest level disclosed for a controlling shareholder.

\subsection{Does the controlling party maximise his/her self-interest to the detriment of the other party?}

In order to answer the second research question the results of the first research 
question were used. To determine the maximisation of self-interest, profit attributable to shareholders is used as the proxy for shareholders' interest and directors' remuneration as a proxy for directors' interest. Both are normalised as a percentage of the total assets of their respective companies, including intangible assets. As companies use their total assets to generate the rewards attributable to the shareholders or directors, total assets is a suitable measure to normalise the rewards generated by the company. Normalising the directors' remuneration and profit attributable to shareholders as a percentage of total assets enables intercompany comparisons between the companies. The use of these proxies is in line with the executive compensation and profitability measures used by Berle and Means (1933:94) and Stigler and Friedland (1983:249, 254).

\section{4}

\section{Research method}

The research questions were empirically answered by extracting secondary data on the companies from the McGregor's BFA database, supplemented with information on control, and on the major shareholders extracted from Profile stock exchange handbook for the relevant controlling periods. All the extracted information was captured into Excel and imported into SPSS version 19 for analysis. The collected data included the companies' names, total assets, directors' remuneration, profit attributable to ordinary shareholders, the percentage shareholding of the largest shareholders, and notes on instances where a major shareholder was also on the board of directors. To ensure that data is comparable between the different companies, the following two variables were calculated for each company to normalise the data:

1) Profit attributable to ordinary shareholders as a percentage of total assets (including intangible assets), and

2) Directors' remuneration as a percentage of total assets (including intangible assets).

These variables represent the different interests between shareholders' (variable 1) and directors' (variable 2) self-interest maximisation. In line with agency theory and agency cost
(Jensen \& Meckling, 1976) and the separation of ownership and control (Berle \& Means, 1933) given the maximisation of self-interest, it is expected that the directors will maximise directors' remuneration whereas the shareholders will maximise the profit attributable to them in the companies they control.

The recorded shareholding (as extracted from Profile) of the largest owners was used to answer the first research question by identifying which companies are controlled by a major shareholder and which are controlled by the directors. Answering the second research question was more complex. Before the question could be answered, the study needed to use the results of the first question that identified the companies controlled by directors and those controlled by shareholders. The identification of control is necessary to determine if the controlling source in the company acted to maximise direct financial self-interest. Based on the factors identified the companies were grouped into two categories, namely companies controlled by shareholders and companies controlled by directors. SPSS was used to analyse whether companies controlled by directors pay higher remuneration to the directors, and if companies controlled by shareholders generate more profit attributable to shareholders.

By focusing on directors' remuneration (the directors' reward) and profit (the shareholders' reward) this study can be compared to the studies of Berle and Means (1933:94) and Stigler and Friedland $(1983: 249,254)$ that focused on the link between control, directors' remuneration and profit in the USA. Profitability and directors' remuneration are used as the basic measures to show the maximisation of individual interest between the shareholders as owners and directors as managers of the owners' assets.

The percentage shareholding of the smallest disclosed controlling shareholding at 25.1 per cent was used to determine the cut-off point to classify companies into their controlling groups. The rounded figure of 25 per cent was used in the classification of control. The first group included companies with a shareholder with 25 per cent or more shares and were classified as controlled by shareholders. The second group is made up by default of 
companies not controlled by a dominant shareholder and were classified as controlled by directors. It was deemed that companies not controlled by a dominant shareholder are in the position where the directors have de facto control, becoming companies controlled by directors. When it was disclosed that a company was controlled by the directors the company was classified as controlled by directors. In the case of companies controlled by directors who were also controlling shareholders, the companies were classified as controlled by shareholders because the voting power of shareholders is the more dominant power.

\section{5}

\section{Results}

\subsection{First research question}

The first research question asked if there is separation of ownership and control in South African-listed companies. The results show that separation of ownership and control exists but shareholding is not yet widely diffused. Just over half of the companies from the 2006 and 2010 controlling periods are controlled by shareholders. The directors controlled over 88 companies (47.3 per cent) in 2006 and over 85 companies (45.7 per cent) in 2010 . This is in line with the 44 per cent managementcontrolled corporations identified by Berle and Means (1933:94) and confirmed by Stigler and Friedland (1983:249, 254). Only six companies disclosed directors' shareholding as a major shareholder, with the shareholding ranging from 5.3 per cent to 24.7 per cent for both controlling periods.

The evaluation of the majority shareholder resulted in an average size majority shareholding of 32.36 per cent for 2006 and 31 per cent in 2010. The study found that the majority of listed companies in South Africa are controlled by a dominant shareholder. The controlling interests for the 2006 and 2010 periods are shown in Table 2.

Table 2

Controlling interest

\begin{tabular}{|c|c|c|}
\hline \multicolumn{3}{|c|}{ Controlling interest 2006} \\
\hline & Frequency & Percentage \\
\hline Controlled by directors & 88 & 47.3 \\
\hline Controlled by shareholders & 98 & 52.7 \\
\hline Total & 186 & 100.0 \\
\hline \multicolumn{3}{|c|}{ Controlling interest 2010} \\
\hline & Frequency & Percentage \\
\hline Controlled by directors & 85 & 45.7 \\
\hline Controlled by shareholders & 101 & 54.3 \\
\hline Total & 186 & 100.0 \\
\hline
\end{tabular}

The disclosed majority shareholding of companies ranged from 5.4 per cent to 91.8 per cent in 2006 and 2.8 per cent to 91.8 per cent in 2010 , with a median of 26.95 per cent in 2006 and 27.5 per cent in 2010 and an average size majority shareholding of 32.36 per cent for 2006 and 31 per cent in 2010. An analysis of the average large shareholding in the study of Shleifer and Vishny (1986:462) on companies in the Fortune 500 found the average percentage shareholding of large shareholders to be 15.4 per cent, smaller when compared to the averages found in this study. This could indicate that the developing nature of the South
African economy with its smaller, less liquid stock exchange might have a negative influence on the diversity of shareholding. The results of the data extraction and analysis are described below under the discussion of the second research question.

As just more than half of the companies are still controlled by directors, separation of ownership and control in South Africa is still in the early stages of its development when compared to the more sophisticated markets in the USA, which already showed greater shareholder diffusion with most of the companies under the de facto control of the 
directors, as disclosed in Table 1. Although the shareholdings in South African companies are not as widely diffused as in the USA, there is still a level of separation between shareholders and directors, with a large number of companies under the control of the directors. Thus the assumption that there is separation of ownership and control is applicable to South African-listed companies.

\subsection{Second research question}

The second research question asks if the controlling party maximises his/her selfinterest to the detriment of the other party. The controlling interest that grouped the companies between director controlled and shareholder controlled companies as shown in Table 2 was used to identify whether they maximised their self-interest. The calculated variables Directors' remuneration as a percentage of total assets and Profit attributable to ordinary shareholders as a percentage of total assets are continuous variables. Descriptive statistics were used to compare the averages or means, to determine whether the means give any indication of the maximisation of self-interest on the part of the controlling party. The results of the descriptive statistics are shown in Table 3.

Table 3

Descriptive statistics

\begin{tabular}{|c|c|c|c|}
\hline \multicolumn{2}{|c|}{2006 Controlling period covering data for 2005 and 2006} & $\mathbf{N}$ & Mean \\
\hline \multirow{2}{*}{ Directors' remuneration as a percentage of assets 2006} & Controlled by directors & 88 & 1.1331 \\
\hline & Controlled by shareholders & 98 & 1.4528 \\
\hline \multirow{2}{*}{ Directors' remuneration as a percentage of assets 2005} & Controlled by directors & 88 & 1.2820 \\
\hline & Controlled by shareholders & 98 & 1.6650 \\
\hline \multirow{2}{*}{ Profit as a percentage of assets 2006} & Controlled by directors & 88 & 9.1623 \\
\hline & Controlled by shareholders & 98 & 10.9288 \\
\hline \multirow{2}{*}{ Profit as a percentage of assets 2005} & Controlled by directors & 88 & 8.6050 \\
\hline & Controlled by shareholders & 98 & 8.2433 \\
\hline \multicolumn{2}{|c|}{2010 Controlling period covering data for 2009 and 2010} & $\mathbf{N}$ & Mean \\
\hline \multirow{2}{*}{ Directors' remuneration as a percentage of assets 2010} & Controlled by directors & 85 & .5487 \\
\hline & Controlled by shareholders & 101 & 1.6806 \\
\hline \multirow{2}{*}{ Directors' remuneration as a percentage of assets 2009} & Controlled by directors & 85 & .4796 \\
\hline & Controlled by shareholders & 101 & 1.4733 \\
\hline \multirow{2}{*}{ Profit as a percentage of assets 2010} & Controlled by directors & 85 & 6.3433 \\
\hline & Controlled by shareholders & 101 & 3.2029 \\
\hline \multirow{2}{*}{ Profit as a percentage of assets 2009} & Controlled by directors & 85 & 6.1971 \\
\hline & Controlled by shareholders & 101 & 3.6995 \\
\hline
\end{tabular}

The results from the descriptive statistics show that the average of directors' remuneration as a percentage of total assets is less for companies controlled by directors in both controlling periods in all four years, with the average profit attributable to shareholders as a percentage of total assets higher for companies controlled by directors in 2005, 2009 and 2010. The exception is in the 2006 year when the shareholder controlled companies generated a higher average profit attributable to shareholders as a percentage of total assets.

The results show that the influence of selfinterest of the controlling parties was the opposite of what was expected, with one exception when in 2006 profit attributable to shareholders was higher on average for companies controlled by shareholders. The results show that the consequences of control result in the maximisation of the interest of the other party to the detriment of the controlling party. The findings were opposite from the expected impact and do not fully support the maximisation of self-interest principle. It could be that the South African corporate governance principle of ubuntu, where ubuntu is a reflection of the interdependence of humanity (IoD, 2002:18-19, 91), counters the maximisation of direct financial self-interest. In essence, it was surprising that the controlling group was 
not the recipient of the larger financial benefit, but that they received a slightly smaller direct financial benefit while the non-controlling group received a slightly larger direct financial benefit. It could also be that control itself has a cost or intangible value that is discounted, thereby requiring the controlling party to pay for the privilege of control through a reduced direct financial benefit. Further statistical analysis was performed using independent sample t-tests to determine if the differences were statistically significant. The results of these tests are included in Table 4.

Table 4

Independent t-tests

\begin{tabular}{|c|c|c|c|c|c|c|c|}
\hline & \multicolumn{2}{|c|}{$\begin{array}{l}\text { Controlled by } \\
\text { directors }\end{array}$} & \multicolumn{2}{|c|}{$\begin{array}{l}\text { Controlled by } \\
\text { shareholders }\end{array}$} & \multirow[b]{2}{*}{$\begin{array}{l}\text { Levene's test } \\
\text { p-value }\end{array}$} & \multicolumn{2}{|c|}{$\begin{array}{l}\text { t-test for equality } \\
\text { of means }\end{array}$} \\
\hline & Mean & $\begin{array}{l}\text { Standard } \\
\text { deviation }\end{array}$ & Mean & $\begin{array}{l}\text { Standard } \\
\text { deviation }\end{array}$ & & $\mathbf{t}$ & $p$-value \\
\hline $\begin{array}{l}\text { Directors' remuneration as a } \\
\text { percentage of assets } 2005\end{array}$ & 1.2820 & 2.28241 & 1.6650 & 3.04158 & .286 & -.962 & .337 \\
\hline $\begin{array}{l}\text { Directors' remuneration as a } \\
\text { percentage of assets } 2006\end{array}$ & 1.1331 & 1.85194 & 1.4528 & 2.20685 & .467 & -1.064 & .289 \\
\hline $\begin{array}{l}\text { Directors' remuneration as a } \\
\text { percentage of assets } 2009\end{array}$ & .4796 & .60606 & 1.4733 & 2.32730 & $.001^{\star *}$ & -4.128 & $.001^{* *}$ \\
\hline $\begin{array}{l}\text { Directors' remuneration as a } \\
\text { percentage of assets } 2010\end{array}$ & .5487 & .72032 & 1.6806 & 2.85120 & $.001^{\star *}$ & -3.846 & $.001^{* *}$ \\
\hline $\begin{array}{l}\text { Profit as a percentage of } \\
\text { assets } 2005\end{array}$ & 8.6050 & 11.47548 & 8.2433 & 19.48208 & .919 & .152 & .879 \\
\hline $\begin{array}{l}\text { Profit as a percentage of } \\
\text { assets } 2006\end{array}$ & 9.1623 & 9.17442 & 10.9288 & 18.70222 & .155 & -.803 & .423 \\
\hline $\begin{array}{l}\text { Profit as a percentage of } \\
\text { assets } 2009\end{array}$ & 6.1971 & 7.39639 & 3.6995 & 17.66265 & $.012^{*}$ & 1.293 & .307 \\
\hline $\begin{array}{l}\text { Profit as a percentage of } \\
\text { assets } 2010\end{array}$ & 6.3433 & 8.85948 & 3.2029 & 29.19029 & $.036^{*}$ & 1.026 & .198 \\
\hline
\end{tabular}

*Significant at $5 \%$ level, **Significant at $1 \%$ level

\subsection{Independent t-test for the $\mathbf{2 0 0 6}$ controlling period}

The independent sample t-test was conducted for the 2006 controlling period. The test compare directors' remuneration as a percentage of assets, and profit attributable to shareholders as a percentage of assets, for companies controlled by directors, with companies controlled by shareholders, for 2005 and 2006 . There was no significant difference between directors' remuneration as a percentage of assets' scores for companies controlled by directors despite the average directors' remuneration at (average or mean $m$ ) $m=1.2820$ (2005) and $m=1.1331$ (2006) being lower than the average directors' remuneration of companies controlled by shareholders at $m=1.6650$ (2005) and $m=1.4528$ (2006). In addition, there was no significant difference between profit attributable to shareholders as a percentage of assets' scores for companies controlled by directors. However, the differences in means fluctuate between the controlling parties over the two periods, $m=8.6050$ (2005) and $m=9.1623$ (2006), and for companies controlled by shareholders $m=8.2433$ (2005) and $m=10.9288$ (2006).

\subsection{Independent t-test for the 2010 controlling period}

The independent sample t-test was conducted for the 2010 controlling period. The test compare the directors' remuneration as a percentage of assets, and the profit attributable to shareholders as a percentage of assets, for companies controlled by directors, and companies controlled by shareholders, for 2009 and 2010. A comparison of the averages or means of the directors' remuneration as a percentage of assets generated by companies controlled by directors was less at $m=.4796$ (2009) and $m=.5487$ (2010) than the average directors' remuneration as a percentage of assets generated by companies 
controlled by shareholders with averages of $m=1.4733$ (2009) and $m=1.6806$ (2010). The same pattern was apparent as a comparison of the means of the profit attributable to shareholders as a percentage of assets generated by companies controlled by directors was more at $m=6.1971$ (2009) and $m=6.3433$ (2010) than the average profit attributable to shareholders as a percentage of assets generated by companies controlled by shareholders with averages of $m=3.6995$ (2009) and $m=3.2029$ (2010).

The independent t-test found these differences to be statistically significant. Thus in 2010 companies controlled by directors generated less value for themselves through a lower directors' remuneration, $(t=-3.846$, $d f=114.956, \quad p=.001)$ following on the pattern from $2009(t=-4.128, d f=115.870$, $p=.001)$; while companies controlled by shareholders generated less value for themselves through a lower profit attributable to shareholders in $2010(t=1.026, d f=121.359$, $p=.307)$ also following on the 2009 pattern $(t=1.293, d f=138.839, p=.198)$.

The assumption that directors or shareholders will act to maximise their direct financial self-interest is not supported by an evaluation of the averages (or means) or by the results of the independent t-tests. Although the 2006 controlling period did not show any statistically significant variances, the differences for the 2010 controlling period are statistically significant. The results of the analysis indicate that the controlling party acts in the best interest of the other party and maximises the direct financial benefit attributed to the noncontrolling party at the cost of the controlling party. This is in contrast to the neo-classical economic assumption that the parties will act to maximise their self-interest. It could be that there is an inherent cost to control that accrues to the controlling party. Cheffins and Bank (2009:462) noted that banks do not adopt a control-centred investment strategy for their trust funds possibly because they then run the risk of inferior returns when compared with more diversified investment strategies, indicating that having a controlling interest could have an inherent cost of control. It could be that the smaller size of the South African economy and market influences the actions of the controlling party. Tsipouri and Xanthakis (2004:18) indicated that "there is a risk of not having enough people to fill the boards in small countries". Thus the availability of competent directors can be a factor. PricewaterhouseCoopers (PWC) found that the pool of available non-executive directors in South Africa is shrinking (PWC, 2011). Because the structure of a firm allows for the separation of ownership and control in companies, both parties need each other. Directors could use simple market forces to attract shareholders by managing the company in a manner that generates higher profits for the shareholders, whereas shareholders need the skills of specialist managers. These skills are also in short supply and shareholders might be prepared to pay a premium to attract good specialist managers.

\section{6}

\section{Conclusions, limitations and further research}

The majority of listed companies in South Africa are controlled by a dominant shareholder. However, there are still a significant number of companies where the directors have de facto control. Contrary to the expectation that companies controlled by directors will aim to maximise directors' remuneration, and that companies controlled by shareholders will aim to maximise the profit attributable to shareholders, this study found the opposite to be true.

Although the fact that the majority of listed companies in South Africa are controlled by a dominant shareholder, the levels of separation of shareholder from control over the company are still evolving towards high levels of shareholder diffusion as the local market expands and increases its sophistication. Despite not being in the majority, there are a significant number of companies where the directors have de facto control and the separation of shareholders and control is more pronounced.

With regard to the maximisation of selfinterest by the controlling party, the reduction in the average directors' remuneration as a percentage of total assets earned by directors in companies controlled by directors, while 
companies controlled by shareholders pay a slightly larger directors' remuneration, is contrary to the neo-classical assumption of self-interest. As this study used the most direct outcome as proxies for the maximisation of self-interest, further studies can consider other proxies that consider indirect benefits to the parties as well. In addition, it is possible that control has a cost, as the controlling parties mostly maximised the most direct value of the other party. This was found to be statistically significant in the 2010 controlling period. As the profit attributable to shareholders as a percentage of total assets was mostly higher for the companies controlled by directors than for the companies controlled by shareholders, it suggests that directors are also profit orientated. A limitation of this study was that it used only two controlling periods, so a further study can extend the periods to determine if the pattern observed for the 2010 controlling period extends into the future.

A further limitation of this study is its focus on the basic building blocks of the agency theory, the separation of ownership and control in companies and the most direct consequences of the control, either via profit attributable to shareholders or directors' remuneration payable to the managers or directors of the companies. Because of the focus on the most direct financial consequences, the impact of other indirect or non-financial advantages to the parties needs to be considered in a future study. In addition, further research on the impact of the sources of funding on firm performance and on the profit attributable to shareholders, as well as directors' remuneration, can lead to improved insight into the role of the different sources used to finance a company and their contribution to firm performance.

\section{References}

AFSHAN, N., CHHETRI, P. \& PRADHAN, S. 2011. Board, ownership structure \& pay and firm performance: A literature review. IUP Journal of Corporate Governance, 10(2):82-92.

ALCHIAN, A.A. \& DEMSETZ, H. 1972. Production, information costs, and economic organization. The American Economic Review, 62(5):777-795.

BABATUNDE, M.A. \& OLANIRAN, O. 2009. The effects of internal and external mechanisms on governance and performance of corporate firms in Nigeria. Corporate Ownership \& Control, 7(12):330-343. BERLE, A.A. \& MEANS, G.C. 1933. The modern corporation and private property, New York: The Macmillan company.

BRATTON, W.W. 2001. Berle and Means reconsidered at the century's turn. Journal of Corporation Law, Spring:737-769.

BRENNAN, N.M. \& SOLOMON, J. 2008. Corporate governance, accountability and mechanisms of accountability: An overview. Accounting, Auditing \& Accountability Journal, 21(7):885-906.

CHEFFINS, B. \& BANK, S. 2009. Is Berle and Means really a myth? Business History Review, 83(3): 443-472.

CHO, D. \& KIM, J. 2007. Outside directors, ownership structure and firm profitability. Corporate Governance: An International Review, 15(2):239-250.

COHEN, T. \& ULIANA, E. 1990. An evaluation of corporate ownership structures on employee, management and shareholder compensation for JSE companies. De Ratione, 4(1):7-14.

CREMERS, K.J.M. \& NAIR, V.B. 2005. Governance mechanisms and equity prices. The Journal of Finance, 60(6):2859-2894.

DALTON, D.R., HITT, M.A., CERTO, S.T. \& DALTON, C.M. 2007. The fundamental agency problem and its mitigation: Independence, equity, and the market for corporate control. Academy of Management Annals, $1: 1-64$.

FAMA, E.F. \& JENSEN, M.C. 1983a. Agency problems and residual claims. Journal of Law and Economics, 26(2):327-350.

FAMA, E.F. \& JENSEN, M.C. 1983b. Seperation of ownership and control. Journal of Law and Economics, 26(2):301-326. 
GAREN, J.E. 1994. Executive compensation and principal-agent theory. The Journal of Political Economy, 102(6):1175-1199.

HILL, J. \& YABLON, C.M. 2002. Corporate governance and executive remuneration: Rediscovering managerial positional conflict. UNSW Law Journal, 25(2):294-319.

IOD 1994. The King report on corporate governance, Johannesburg, Institute of Directors.

IOD 2002. King report of corporate governance for South Africa, Johannesburg, Institute of Directors.

IOD 2009. King code of governance for South Africa 2009, Johannesburg, Institute of Directors.

JENSEN, M.C. 2001. Value maximisation, stakeholder theory, and corporate obejective function. European Financial Management, 7(3):297-317.

JENSEN, M.C. \& MECKLING, W.H. 1976. Theory of the firm: Managerial behaviour, agency cost and ownership structure. Journal of Financial Economics, 3(4):305-360.

JENSEN, M.C. \& MURPHY, K.J. 1990. Performance pay and top-management incentives. Journal of Political Economy, 98(2):225-264.

JIANG, H., HABIB, A. \& SMALLMAN, C. 2009. The effect of ownership concentration on CEO compensation - firm performance relationship in New Zealand. Pacific Accounting Review, 21(2):104-131. LEE, S.H., MICHIE, J. \& OUGHTON, C. 2003. Comparative corporate governance: beyond 'shareholder value'. Journal of Interdisciplinary Economics, 14(2):81-111.

MORCK, R., SHLEIFER, A. \& VISHNY, R.W. 1988. Management ownership and market valuation: An empirical analysis. Journal of Financial Economics, 20:293-315.

O'SULLIVAN, N. \& DIACON, S.R. 1999. Internal and external governance mechanisms: evidence from the UK insurance industry. Corporate Governance: An International Review, 7(4):263-373.

PROFILE 2006. Profile's Stock Exchange Handbook, Johannesburg: Profile Media.

PROFILE 2010. Profile's Stock Exchange Handbook, Johannesburg: Profile Media.

PWC 2011. Non-executive directors: Practices and fees trends report. PricewaterhouseCoopers.

ROSSOUW, G.J., VAN DER WATT, A. \& MALAN, D. 2002. Corporate governance in South Africa. Journal of Business Ethics, 37(3):289-302.

RSA 2008. Companies Act, No 71 of 2008. Pretoria: Government printer.

SETIA-ATMAJA, L.Y. 2009. Governance mechanisms and firm value: the impact of ownership concentration and dividends. Corporate Governance: An International Review, 16(6):694-709.

SHAPIRO, S.P. 2005. Agency theory. Annual Review of Sociology, 31:263-284.

SHLEIFER, A. \& VISHNY, R.W. 1986. Large shareholders and corporate control. Journal of Political Economy, 94(3):461-488.

SINGH, M. \& DAVIDSON, W.N. 2003. Agency costs, ownership structure and corporate governance mechanisms. Journal of Banking \& Finance, 27(5):793-816.

STEMPEL, J. 2010. Buffett, world's 3rd richest person, gets pay rise. Reuters. Available at: http://www.reuters.com/assets/print?aid=USTRE62A5SH20100311 [accessed 2012-04-21].

STIGLER, G.J. \& FRIEDLAND, C. 1983. The literature of economics: the case of Berle and Means. Journal of Law and Economics, XXVI:237-268.

TREANOR, J. 2012. Row grows over Barclays chief's pay and $£ 5.7 \mathrm{~m}$ tax bill The Guardian Available at: http://www.guardian.co.uk/business/2012/apr/10/barclays-chief-pay-award-warning [accessed 2012-03-24]. TSIPOURI, L. \& XANTHAKIS, M. 2004. Can corporate governance be rated? Ideas based on the Greek experience. Corporate Governance : An International Review, 12(1):16-28.

WARD, A.J., BROWN, J.A. \& RODRIGUEZ, D. 2009. Governance bundles, firm performance, and the substitutability and complementarity of governance mechanisms. Corporate Governance: An International Review, 17(5):646-660.

WESTBROOK, D.A. 2003. Corporation law after Enron: The possibility of a capitalist reimagination. The Georgetown Law Journal, 92:61-125. 